\title{
POLA JARINGAN KOMUNIKASI PADA PARTISIPASI POLITIK AKAR RUMPUT (STUDI NETNOGRAFI MEDIA SOSIAL TWITTER PADA AKSI BELA ISLAM)
}

\section{COMMUNICATION NETWORK PATTERNS IN POLITICAL GRASS ROOT PARTICIPATION (NETNOGRAPHIC STUDY OF TWITTER SOCIAL MEDIA IN “AKSI BELA ISLAM")}

\author{
Rofi'ah $^{1,2}$, Sumardjo $^{3}$, Sarwititi Sarwoprasodjo ${ }^{4}$, Djuara P Lubis ${ }^{5}$ \\ ${ }^{1}$ Mahasiswa pascasarjana Komunikasi Pembangunan, IPB University, Bogor, Indonesia \\ ${ }^{2}$ Departemen Komunikasi Penyiaran Islam, Universitas Ibn Khaldun, Bogor, Indonesia \\ ${ }_{3,4,5}$ Departemen Komunikasi Pembangunan, IPB University, Bogor, Indonesia \\ 1,2 rofiahsiddiq@gmail.com, ${ }^{3}$ sumardjo252@gmail.com, ${ }^{4}$ sarwititisarwoprasodjo@gmail.com, \\ ${ }^{5}$ djuaralubis@gmail.com \\ Diterima tgl. 01/10/2020; Direvisi tgl. 03/05/2021; Disetujui tgl. 17/05/2021
}

\begin{abstract}
The meeting of various political narratives in the virtual public sphere often triggers conflict. In the "aksi bela Islam" conflict occurs as a result of individuals and communities carrying different meanings being connected in communication networks. The research is analyze how the social media Twitter forms these various connections. This is a qualitative study with a netnographic approach, from a communication network perspective. The results indicate two patterns of communication networks in interpreting the "aksi bela Islam" as a political event. First, a centralized communication network that creates polarization that forms two large narratives, which contradict and resulting conflict of a political idea. Polarization by trending hashtag. Second, a spread and open communication networks. This model opens a communication space that is dialogical and convergent among communities. This pattern is mediated by the formation of a common community through the similarity of words marked with a hashtag so that there is a connection between groups in a communication network. By understanding the conflict patterns shown by the communication network patterns that are formed, it can be a recommendation in an appropriate conflict resolution effort.
\end{abstract}

Keywords: Communication Networks, Twitter Netnography, Political Participation.

\begin{abstract}
ABSTRAK
Bertemunya beragam narasi politik di ruang publik virtual seringkali menjadi konflik. Dalam peristiwa aksi bela Islam konflik terjadi akibat individu dan komunitas yang memiliki makna berbeda atas aksi bela Islam terkoneksi dalam jaringan-jaringan komunikasi.Tujuan penelitian ini adalah tentang bagaimana media sosial Twitter membentuk beragam koneksi tersebut. Penelitian ini merupakan penelitian kualitatif dengan pendekatan netnografi perspektif analisis jaringan komunikasi. Temuan penelitian ini menunjukkan terdapat dua pola jaringan komunikasi dalam memaknai aksi bela Islam sebagai peristiwa politik. Pertama, jaringan komunikasi yang bersifat terpusat sehingga menciptakan polarisasi yang membentuk dua narasi besar, yang saling bertentangan dan mengakibatkan terjadinya konflik. Narasi eksklusif kedua belah pihak berupa saling mengklaim kebenaran suatu ide politik. Penyebab polarisasi adalah beradu trending tagar. Kedua, jaringan komunikasi yang bersifat menyebar dan terbuka. Model ini membuka ruang komunikasi yang bersifat dialogis dan konvergen di antara komunitas-komunitas yang ada di Twitter. Pola ini dimediasi oleh terbentuknya komunitas bersama melalui kesamaan kata bertanda pagar sehingga terjadi koneksi antar kelompok dalam suatu jaringan komunikasi. Dengan memahami pola konflik yang ditunjukkan oleh polapola jaringan komunikasi dapat menjadi rekomendasi dalam upaya penanganan konflik yang tepat.
\end{abstract}

Kata Kunci: Jaringan Komunikasi, Netnografi Twitter, Partisipasi Politik.

\section{PENDAHULUAN}

Fenomena aksi bela Islam terus menjadi perhatian dengan berbagai kecurigaan yang dialamatkan terhadapnya (Lim, 2017). Besarnya perhatian terutama karena adanya dua narasi besar yang saling berhadapan dalam memaknai aksi bela Islam karena perbedaan sudut pandang terkait 
aksi bela Islam, seperti antara sudut pandang sebagai politik identitas yang berbahaya bagi kelangsungan demokrasi (Khamdan \& Wiharyani, 2018) dengan sudut pandang bahwa aksi bela Islam adalah sebagai ijtihad politik sekelompok kaum muslim (Abdullah, 2017). Keragaman partisipasi politik akar rumput cenderung memicu konflik ketika bertemu di ruang publik, terutama pada musim politik elektoral. Musim pemilu menjadikan semua peristiwa dihubungkan dengan perebutan kekuasaan politik. Aksi bela Islam dihubungkan dengan pertarungan politik pilkada Jakarta tahun 2017 dan menicu konflik antar pendukung dua kandidat Gubernur Jakarta dengan cara saling berbalas aksi. Konflik menjadi semakin besar terutama di media sosial ketika kebebasan menyatakan pendapat disertai anonimitas yang disediakan internet menjadi sarana ujaran kebencian untuk merendahkan lawan politiknya (Lim, 2017). Pada fenomena aksi bela Islam konflik di ruang publik virtual berbentuk narasi-narasi dua kelompok yang berbeda pandangan tersebut. Narasi yang pertama adalah aksi bela Islam sebagai cara menunjukkan sikap kritis terhadap pemerintah dalam hal penegakan hukum penistaan agama (Susilowati et al., 2019). Narasi yang kedua adalah aksi bela Islam sebagai bentuk intoleransi komunitas Islam radikal terhadap komunitas minoritas (Hamudy, 2019). Kedua narasi ini menjadi media terbentuknya jaringan-jaringan komunikasi di media sosial Twitter berdasarkan terkoneksinya individu-individu yang menyatakan pendapat terkait aksi bela Islam. Jaringan komunikasi menggambarkan relasi aktor (bisa orang, lembaga, perusahaan, negara dan sebagainya) satu dengan lainnya dalam struktur sosial tertentu (Eriyanto 2014 dalam Hapsari et al., 2017). Setiap individu menjalin komunikasi dengan sesamanya melalui proses interaksi yang terjadi sehingga menciptakan suatu pola relasi antarindividu dari hasil interaksi yang terbentuk. Pada tingkat analisis jaringan, proses komunikasi melibatkan hubungan sehingga dikatakan jaringan komunikasi apabila struktur yang dibangun didasarkan pada hubungan komunikasi (Hapsari et al., 2017).

Berbagai kebijakan pemerintah terkait fenomena aksi bela Islam yang menyoroti keragaman organisasi Islam dalam aksi bela Islam juga menjadi penyabab konflik. Dalam pandangan pemerintah aksi bela Islam dapat menimbulkan kekhawatiran terganggunnya stabilitas nasional karena berpotensi ditunggangi kelompok Islam radikal, bahkan massa aksi bela Islam itu sendiri menjadi massa radikal (Wijayanto \& Purworini, 2018). Narasi dari pemerintah ini kemudian menjadi dasar dari terbentuknya narasi publik, yaitu bahwa aksi bela Islam adalah bentuk gerakan intolerasi. Narasi inilah yang kemudian berhadapan dengan narasi politik dari massa aksi bela Islam dan menjadi konflik karena masyarakat terus terpolarisasi hingga tahun-tahun berikutnya. Konflik dapat terjadi karena perbedaan pemahaman atas suatu fenomena tertentu di antaranya karena terdapat perbedaan budaya (Rofi'ah, 2013). Hal ini dapat berdampak secara nyata di dalam kehidupan sosial, terutama dalam kondisi modal sosial yang belum mapan di dalam suatu masyarakat (Sumardjo, 2015) di samping penanganan konflik yang belum tepat serta belum optimalnya peran pemerintah (Sumardjo, 2008, 2010, 2015). Meskipun menjadi fenomena yang kontroversial (Syahputra, 2017), sebagaimana diberitakan oleh detik.com. "Pantauan detik.com di Monas, Jakarta Pusat, Jumat (2/12/2016), massa peserta aksi yang mengenakan pakaian putih-putih duduk dengan tertib. Dari pantauan udara terlihat area rumput tidak diduduki (Fadhil, 2016), baik pemerintah maupun massa kontra aksi ini mengakui demo yang berjalan damai.

Adapun di media sosial Twitter, kedua narasi ini berkonflik dalam bentuk perang tagar yang menggambarkan jaringan komunikasi terpusat pada kelompok masing-masing. Perang tagar yang mengakibatkan politik polarisasi massa pada fenomena aksi bela Islam sudah terjadi sejak 2016 lalu dan berlanjut hingga tahun-tahun berikutnya. Terdapat banyak penelitian membuktikan peran Twitter sebagai media mengemukakan pandangan politik (Ahmadian et al., 2017; Anderson, 2017; 
Ausserhofer \& Maireder, 2013; Bos \& Brants, 2014; Juditha, 2015, 2017; Negara, 2020) dan sebagai salah satu tempat terjadinya konflik politik elektoral (Juditha, 2017, 2019) karena Twitter ternyata digunakan sebagai media komunikasi politik terutama oleh kalangan akar rumput (Block \& Negrine, 2017).

Perbedaan penelitian ini dengan penelitian-penelitian sebelumnya terletak pada temuan digunakannya media sosial Twitter sebagai tempat berkonflik sekaligus menyelesaikan konflik antarpandangan politik yang berbeda, terutama melalui interaksi di dalam jaringan komunikasi yang bersifat terbuka, hingga kesepahaman dapat terjadi terhadap berbedaan model partisipasi politik. Partisipasi politik adalah keterlibatan individu atau kelompok sebagai warga negara dalam proses politik yang bertujuan untuk mempengaruhi kebijakan pemerintah (Block \& Negrine, 2017). Block \& Negrine (2017) menjelaskan bahwa partisipasi politik adalah segala keikutsertaan warga negara biasa dalam menentukan segala keputusan yang menyangkut atau memengaruhi hidupnya. Oleh karena itu, menjadi hal yang wajar terjadinya perbedaan model partisipasi individu dan kelompok di dalam berpolitik. Memahami pola jaringan komunikasi dalam konflik politik akar rumput akan dapat menggambarkan bagaimana konflik terjadi dan diselesaikan oleh partisipan politik itu sendiri, sebagaimana temuan penelitian ini.

Artikel ini melakukan kajian terhadap upaya penanganan konflik pemaknaan peristiwa aksi bela Islam menggunakan analisis jaringan komunikasi yang terbentuk di media sosial Twitter pada kurun waktu antara Desember 2016 hingga Mei 2017. Memahami bagaimana jaringan komunikasi tercipta serta tujuan-tujuan terbentuknya jaringan komunikasi tersebut dapat menjadi dasar dalam memahami pola konflik dan juga upaya penanganan konflik yang tepat.

\section{METODE PENELITIAN}

Penelitian ini merupakan penelitian kualitatif dengan menggunakan metode jaringan komunikasi pada suatu fenomena netnografi. Menurut Kozinets et al., (2015) Netnografi adalah observasi berbasis pada partisipan di dunia virtual menggunakan computer mediatedcommunication $(\mathrm{CMC})$ sebagai sumber data utama untuk memperoleh pemahaman etnografi masyarakat online. Dalam hal ini menggali etnografi masyarakat Twitter melalui simbol hashtag dan trending topic. Kedua pola budaya virtual ini menjadi media terkoneksinya individu-individu melalui suatu narasi yang dibagikan di ruang virtual kedalam suatu jaringan komunikasi yang memiliki makna tertentu. Pola hubungan yang menggambarkan relasi antar aktor akan mengungkap makna dari jaringan komunikasi yang terbentuk (Hapsari et al., 2017). Dalam fenomena aksi bela Islam, adanya dua model jaringan komunikasi yang terbetuk mengungkap perbedaan makna dan tujuan dalam berinteraksi di ruang virtual. Artinya analisis jaringan komunikasi merupakan metode penelitian untuk mengidentifikasi struktur komunikasi dalam suatu sistem ketika analisis data relasional dilakukan dengan menggunakan beberapa jenis hubungan interpersonal sebagai unit analisis.

Tagar sebagai salah satu fasilitas yang disediakan Twitter berfungsi untuk mengklasifikasikan percakapan berdasarkan kesamaan tema agar memudahkan pengguna Twitter menemukan dan menanggapi tema yang diinginkan. Percakapan berdasarkan hashtag ini menjadikan para pengakses tema terkoneksi dan berjejaring membentuk sruktur komunikasi dalam suatu komunitas. Dalam menanggapi isu aksi bela Islam, komunitas-komunitas yang terbentuk berdasarkan tema ini terekam di trending topic Twitter dan menunjukkan suatu pola konflik. Hashtag di trending topic yang menjadi data penelitian adalah \#aksibelaislam, \#saveahok, \#NKRIHargaMati, \#IndonesiaDamai, dan \#Makar. Pengambilan data kelima hastag di media sosial Twitter ini 
dilakukan pada bulan Desember 2016 hingga bulan Mei 2017 dengan menggunakan bahasa pemrograman Python pada program twitter search API untuk memanggil semua percakapan yang berisi kata bertagar yang menjadi keyword dalam pengambilan data penelitian ini. Selain itu datadata pendukung lainnya diperoleh dari berbagai sumber seperti jurnal, buku, dan media online yang berkaitan dengan masalah penelitian. Dalam penelitian ini dilakukan pengamatan berkelanjutan hingga tahun 2019 dengan pertimbangan terjadinya konflik yang berkelanjutan. Selanjutnya dilakukan analisa pada aktivitas interaksi warganet yang membentuk realitas virtual (Jr, 2010; Kozinets et al., 2015). Pada data yang diperoleh berdasarkan kelima hashtag yang dipilih tersebut, masing-masing diambil sebanyak limapuluh tweet sebagai sampel dalam penelitian ini, sehingga total sampel penelitian berjumlah duaratus limapuluh tweet. Selanjutnya teknik koding dilakukan dengan mengacu pada konsep jaringan komunikasi, sehingga didapat makna dari berbagai interaksi yang terjadi di media sosial Twitter tersebut.

\section{HASIL DAN PEMBAHASAN}

\subsection{Budaya Masyarakat Twitter: Tanda Pagar (\#)}

Aksi bela Islam muncul sebagai komunitas tagar di Twitter. komunitas aksi bela Islam sebagai suatu komunitas gerakan massa membagikan narasinya di ruang publik virtual berupa tuntutan penegakan hukum atas dugaan penistaan terhadap agama Islam (Nasrullah, 2017; Syahputra, 2017). Penelitian ini menemukan bahwa di dunia virtual, dalam hal ini media sosial Twitter, aksi bela Islam bukan satu-satunya komunitas yang tercipta dalam merespon isu penistaan agama, terdapat juga komunitas lainnya, yaitu komunitas bubarkan FPI, NKRI harga mati, makar, dan Indonesia damai, yang muncul di Twitter sejak akhir 2016 lalu dan merupakan narasi dari kelompokkelompok akar rumput, sebagai bentuk partisipasi politiknya (Tabel 1).

Tabel 1. Komunitas Tagar Warga Twitter yang Membentuk Jaringan Komunikasi

\begin{tabular}{|c|c|c|c|c|c|c|c|}
\hline No & Tagar & $\begin{array}{l}\text { Tahun } \\
\text { Terbentuk }\end{array}$ & $\begin{array}{l}\text { Jumlah } \\
\text { Tweet }\end{array}$ & $\begin{array}{l}\text { Bentuk } \\
\text { Jaringan } \\
\text { Komunikasi }\end{array}$ & Penyebab & Ciri-ciri & $\begin{array}{l}\text { Isi } \\
\text { Percakapan }\end{array}$ \\
\hline 1 & $\begin{array}{l}\text { \#Aksi bela } \\
\text { Islam } \\
\text { \#Bubarkan } \\
\text { FPI }\end{array}$ & $\begin{array}{l}2016 \\
2017\end{array}$ & 50 & $\begin{array}{l}\text { Tagar } \\
\text { eksklusif } \\
\text { membentuk } \\
\text { jaringan } \\
\text { komunikasi } \\
\text { terpolarisasi. }\end{array}$ & $\begin{array}{l}\text { Bahasa } \\
\text { khas } \\
\text { kelompok. }\end{array}$ & $\begin{array}{l}\text { Berdebat } \\
\text { untuk saling } \\
\text { mematika } \\
\text { argumentasi } \\
\text { lawan. }\end{array}$ & $\begin{array}{l}\text { Menolak } \\
\text { perbedaan } \\
\text { dengan ujaran } \\
\text { kebencian, } \\
\text { emosional } \\
\text { dan } \\
\text { Pornografi. }\end{array}$ \\
\hline 2 & $\begin{array}{l}\text { \#Indonesia } \\
\text { damai } \\
\text { \#NKRI } \\
\text { Harga Mati } \\
\text { \#Makar }\end{array}$ & $\begin{array}{l}2017 \\
2017 \\
2017\end{array}$ & $\begin{array}{l}50 \\
50\end{array}$ & $\begin{array}{l}\text { Tagar } \\
\text { inklusif } \\
\text { membentuk } \\
\text { jaringan } \\
\text { komunikasi } \\
\text { menyebar. }\end{array}$ & $\begin{array}{l}\text { Bahasa } \\
\text { umum } \\
\text { bersama. }\end{array}$ & $\begin{array}{l}\text { Komunikasi } \\
\text { dialogis dan } \\
\text { konvergen } \\
\text { untuk } \\
\text { menemukan } \\
\text { kesepahaman. }\end{array}$ & $\begin{array}{l}\text { Negosiasi } \\
\text { antar } \\
\text { perbedaan } \\
\text { Klarifikasi } \\
\text { data dan bukti } \\
\text { Meredakan } \\
\text { ketegangan } \\
\text { dengan } \\
\text { humor dan } \\
\text { pantun, puisi } \\
\text { dan } \\
\text { Metafora. }\end{array}$ \\
\hline
\end{tabular}


Pada beragam komunitas yang merespon isu penegakan hukum atas penistaan agama di Twitter, terdapat dua komunitas besar yang saling menunjukkan kekuatan dalam menggalang massa di dunia virtual. Upaya penggalangan massa ini antara lain berupa menjadi trending topic di linimasa Twitter untuk mendapatkan perhatian publik. Tanda pagar atau biasa disebut tagar merupakan media dari pembentukan komunitas di media sosial Twitter. Tweet atau kicauan yang menyertakan suatu kata bertagar akan masuk kedalam komunitas tagar tersebut. Artinya komunitas tagar aksi bela Islam adalah sekelompok orang yang menyuarakan pandangannya tentang cara menghadapi fenomena penistaan terhadap agama. Dalam hal ini narasi yang dibangun oleh komunitas tagar aksi bela Islam adalah tuntutan penegakan hukum terhadap sang penista agama. Adapun komunitas tagar bubarkan FPI bersama-sama dengan komunitas save Ahok membangun narasi penolakan terhadap akis bela Islam karena merupakan eksploitasi agama atau menjadikan agama sebagai alat mencapai tujuan kelompok untuk menyingkirkan figur yang tidak disukai oleh kelompok tersebut (Wardani, 2017). Tagar bubarkan FPI dan tagar save Ahok merupakan pola perkembangan isu dari suatu narasi bertagar sebagai narasi kontra terhadap narasi aksi bela Islam. Tagar bubarkan FPI berkembang pada tagar save Ahok, tagar Indonesia tanpa FPI dan tagar tolak khilafah yang muncul hingga tahun 2019 (CNN Indonesia, 2019). Adapun tagar aksi bela Islam berkembang pada tagar tangkap Ahok, tagar kami bersama FPI dan tagar NKRI bersyariah yang juga muncul hingga tahun 2019.

Penelitian ini menghasilkan temuan bahwa perkembangan isu dimediasi oleh budaya menyertakan beberapa tagar dalam suatu tweet. Dalam komunitas save Ahok misalnya, mereka menyertakan tagar bubarkan FPI dalam percakapannya. Hal ini menunjukkan bahwa komunitas tagar bubarkan FPI bergabung dalam komunitas tagar save Ahok yang menjadi trending topic pada 2017, ketika sidang atas perkara penistaan terhadap agama digelar. Selain kedua tagar ini yang membentuk afiliasi kelompok tagar, muncul juga tagar Indonesai tanpa FPI, dan tagar tolak khilafah berbarengan dengan tagar save Ahok yang menjadi trending topic pada tahun 2017 tersebut. Fenomana percakapan yang terjadi dengan menyertakan banyak tagar, menunjukkan bahwa komunitas-komunitas ini membentuk afiliasi antar kelompok tagar dan memiliki pandangan yang sama yaitu sebagai kontra opini dari opini aksi bela Islam.

Selain tagar-tagar yang berafiliasi dengan tagar save Ahok, muncul juga tagar yang menjadi kontra opini dari tagar save Ahok, yaitu tagar tangkap Ahok yang muncul pada tahun 2017. Tagar tangkap Ahok berafiliasi dengn tagar aksi bela Islam yang menjadi trending topic di Twitter pada tahun 2016. Tagar tangkap Ahok juga berhasil menjadi trending topic di Twitter. Adapun tagar kami bersama FPI, tagar NKRI bersyariah yang juga berafiliasi dengan tagar aksi bela Islam menjadi trending topic pada tahun 2019 sebagai kontra opini dari tagar bubarkan FPI. Kemunculan berbagai tagar baik berupa saling berafiliasi maupun berupa kontra, membuat masyarakat Twitter terpolarisasi. (Gambar 1) 


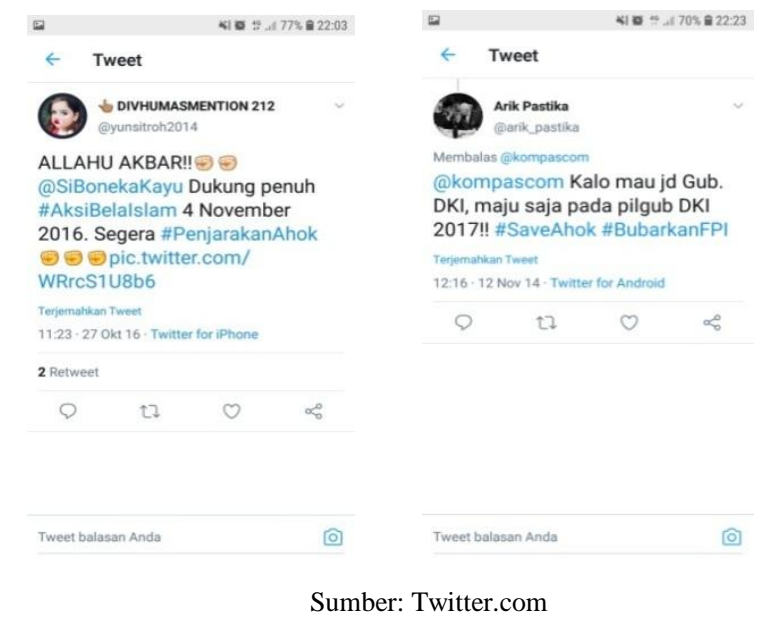

Gambar 1. Sampel Data Penelitian Polarisasi Massa di Twitter

Berdasarkan temuan penelitian terkait keragaman narasi di ruang publik virtual di satu sisi, dan adanya dua narasi besar yang saling berhadap-hadapan sebagai komunitas pro dan komunitas kontra terhadap isu penegakan hukum penistaan agama di sisi lain, maka gambaran jaringan komunikasi yang dapat dipetakan dalam penelitian ini adalah sebagai berikut: terdapat dua pola jaringan komunikasi yang berbeda. Jaringan komunikasi yang pertama berbentuk jaringan komunikasi terpusat, yaitu individu-individu atau aktor-aktor yang terkoneksi dalam suatu jaringan komunikasi berdasarkan kesamaan pandangan. Keterpusatan jaringan ini membentuk sikap eksklusif kelompok sehingga menolak untuk berkomunikasi dengan individu atau kelompok yang memilki pendapat berbeda. Pola ini dimediasi oleh narasi bertagar dengan menggunakan bahasa eksklusif seperti "aksi bela Islam" dan "bubarkan ormas radikal FPI". Jaringan komunikasi yang kedua berbentuk jaringan komunikasi menyebar, yaitu individu-individu yang terkoneksi berdasarkan kesamaan isu yang ditanggapi, namun memiliki pandangan yang beragam. Pola ini membentuk jaringan komunikasi bersifat inklusif yang dimediasi oleh tagar dengan bahasa yang lebih inklusif seperti "Indonesia Damai" dan "NKRI Harga Mati”. Kedua pola jaringan komunikasi yang terbentuk pada fenomena aksi bela Islam tergambar dalam bagan berikut ini: (Gambar 2)

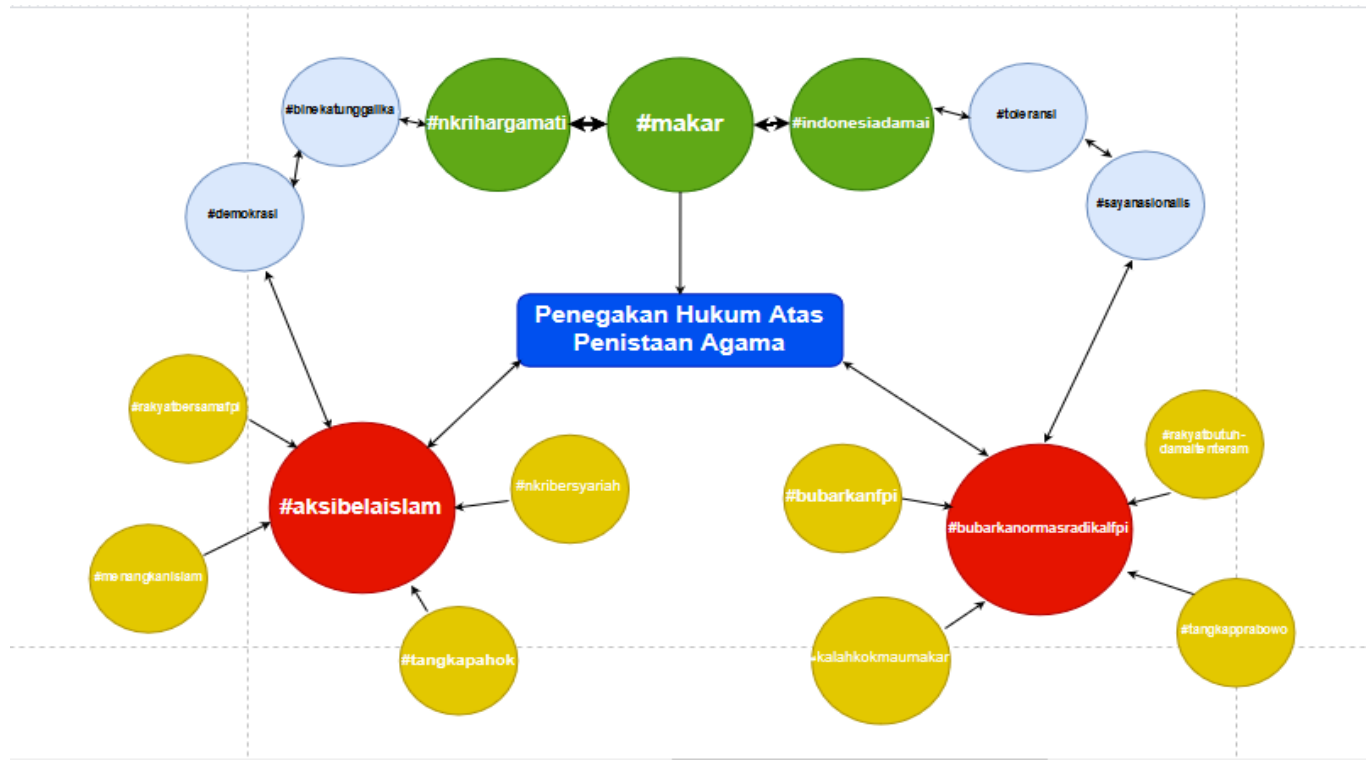

Sumber: Data Primer, Diolah, 2020

Gambar 2. Netnografi Warganet Twitter Membentuk Jaringan Komunikasi 


\subsection{Sebab-Sebab Polarisasi, Jaringan Komunikasi Awal Konflik}

Tagar-tagar yang mengelompok dan menciptakan suatu kesatuan isu menjadikan masyarakat Twitter terpolarisasi kedalam kelompok pro dan kontra. Kelompok-kelompok ini dapat dibedakan melalui narasi yang menggunakan bahasa khas kelompoknya (CNN Indonesia, 2019; Ridhoi, 2018). Temuan penelitian ini menunjukkan bahwa tagar aksi bela Islam misalnya, berkembang pada tagar tangkap Ahok yang muncul pada tahun 2017, tagar kami bersama FPI yang muncul pada tahun 2017 dan tagar NKRI bersyariah yang muncul pada tahun 2017. Sebagai Massa yang mengusung identitas keagamaan, kata-kata yang digunakan dalam membangun narasi kelompok aksi bela Islam menampilkan ciri khas kelompoknya sehingga narasi menjadi nampak eksklusif. Demikian juga yang terjadi pada tagar bubarkan FPI yang berkembang pada tagar save Ahok, tagar Indonesia tanpa FPI dan tagar tolak Khilafah yang muncul pada tahun 2017. Kelompok ini membangun narasi yang mencerminkan kontra narasi tagar aksi bela Islam, dengan menggunakan ciri khas kelompoknya, sehingga terjadi polarisasi yang memecah belah masyarakat Twitter kedalam dua narasi besar, yaitu tagar aksi bela Islam dan tagar bubarkan FPI. Hal ini menunjukkan bahwa keterpusatan jaringan komunikasi menjadi sebab terjadinya konflik berkelanjutan yang semakin membesar, ditandai dengan semakin besarnya pengikut dari kedua tagar tersebut, dan terus menerus menciptakan perang tagar dengan menggunakan narasi-narasi eksklusif.

\subsection{Narasi Inklusif: Jalan Terbukanya Jaringan Komunikasi Dialogis dan Konvergen}

Selain temuan perihal pola jaringan komunikasi terpusat yang menjadi penyebab terjadinya konflik, penelitian ini juga menemukan bahwa tagar-tagar juga berkembang pada narasi yang lebih inklusif. Di media sosial Twitter, ketika suatu tweet atau kicauan menyertakan tagar aksi bela Islam dan tagar NKRI harga mati misalnya, maka kicauan tersebut akan masuk kedalam komunitas tagar aksi bela Islam dan juga masuk kedalam komunitas tagar NKRI harga mati. Artinya akun dengan kicauan tersebut menjadi anggota di kedua komunitas sekaligus. Hal ini mengakibatkan kicauannya dapat ditanggapi oleh komunitas tagar aksi bela Islam dan juga dapat ditanggapi oleh komunitas NKRI harga mati. Demikian juga ketika suatu akun menyertakan tagar bubarkan FPI dan tagar NKRI harga mati di dalam kicauannya, maka kicauan tersebut telah menjadikan sang pemilik akun masuk kedalam dua komunitas, yaitu komunitas tagar bubarkan FPI dan komunitas tagar NKRI harga mati. Maka pada tagar NKRI harga mati itu bertemu juga tagar aksi bela Islam dan tagar bubarkan FPI. (Gambar 3)

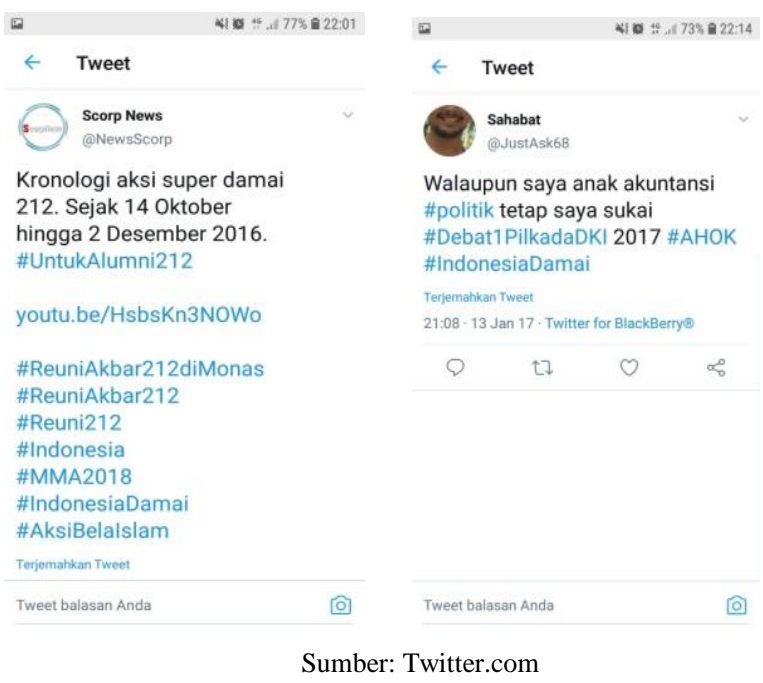

Gambar 3. Proses Terjadinya Jaringan Komunikasi Terbuka Karena Kesamaan Narasi Bertagar 
Budaya menjadi anggota dari beberapa komunitas tagar ini menjadi jalan bagi terbukanya komunikasi di antara komunitas yang terpolarisasi karena mereka menjadi anggota di dalam komunitas yang sama yaitu komunitas NKRI harga mati. Karena terdapat kesamaan sebagai komunitas NKRI harga mati dan terdapat perbedaan sebagi komunitas tagar aksi bela Islam dan komunitas bubarkan FPI, maka terjadi komunikasi di atara mereka dengan topik yang baru, yaitu makna NKRI harga mati bagi kedua belah pihak, bagaimana komunitas tagar aksi bela Islam membuktikan bahwa kelompoknya bagian dari narasi NKRI harga mati, demikian juga sebaliknya, bagaimana komunitas save Ahok membuktikan bahwa kelompoknya bagian dari narasi NKRI harga mati. Pada fenomena aksi bela Islam, tagar-tagar dengan narasi yang inklusif sebagaimana tagar NKRI harga mati banyak bermunculan bersamaan dengan tagar yang terpolarisasi. Bersama tagar aksi bela Islam, disertakan pula tagar NKRI harga mati, tagar demokrasi, tagar bhinneka tunggal ika, tagar toleransi, tagar saya nasionalis, tagar Indonesia damai dan tagar makar. Demikian juga bersama tagar bubarkan FPI, disertakan pula tagar tagar demokrasi, tagar bhinneka tunggal $i k a$, tagar toleransi, tagar saya nasionalis, tagar Indonesia damai dan tagar makar yang muncul pada tahun 2017. Maka di samping sebagai komunitas yang terbelah karena tagar aksi bela Islam dan tagar bubarkan FPI, mereka juga menjadi satu komunitas karena tagar yang inklusif. Jika pada tagar yang terpolarisasi tidak terjadi komunikasi yang efektif dan cenderung saling mematikan pandangan dari opini-opini yang dianggap berseberangan, adanya tagar bersama membuka ruang diskusi tentang makna dari NKRI harga mati, Indonesia damai dan makar. Pada tagar bersama ini terjadi diskusi beragam persepktif, mengkomunikasikan bukti-bukti baik berupa foto, data dan dokumen lainnya, membuka ruang bagi munculnya makna bersama yang disepakati sehingga mengurangi kerasnya polarisasi, kecurigaan, dan kekhawatiran. Pemaparan bukti-bukti atas suatu argumen juga menjadi arena perdebatan sehingga hoaks dapat segera terbongkar.

Interaksi yang lebih bersifat dialogis juga memungkinkan masing-masing komunitas tagar mempertanyakan dampak masing-masing isu yang diusung bagi masa depan Indonesia yang lebih baik. Perdebatan diantaranya tentang cara-cara yang paling benar bagi agama dalam berkontribusi untuk pembangunan Indonesia. Dari perdebatan itu berkembang berbagai masukan dan argumentasi terkait cara beragama yang moderat dan cara beragama yang radikal, di mana masingmasing kelompok saling mengupayakan klaim. Perdebatan juga memunculkan tema fungsi agama antara di ruang publik dan ruang privat, sehingga muncul diskusi terkait fungsi agama bagi pembangunan secara moral individu dan manusia seutuhnya menyangkut ekonomi, politik dan sosial sekaligus. Berdasarkan tema-tema yang diperdebatkan ini, maka tagar bersama menjadi simbol konvergensi komunikasi agar setiap kelompok dapat bernegosiasi tentang ide, pandangan dan klaim tertentu.

Dari klaim-klaim yang didiskusikan, terdapat klaim-klaim yang kemudian disetujui seperti demokrasi, bhinneka tunggal ika, toleransi da nasionalis. Artinya kelompok-kelompok ini bersepakat bahwa terdapat tujuan yang sama dalam merespon isu penegakan hukum atas isu penistaan agama, yaitu saling menghargai pendapat antar kelompok. Bahwa pendapat-pendapat dari beragam kelompok tagar tersebut merupakan upaya berkontribusi untuk masa depan Indonesia yang lebih baik. Komunikasi yang terjadi di dalam jaringan komunikasi yang dimediasi oleh tagar bhinneka tunggal ika, tagar demokrasi, tagar saya nasionalis, dan tagar toleransi berfokus pada ditemukannya pemahaman atas adanya perbedaan cara dalam berdemokrasi, nasionalis, dan toleransi. Pada pola ini komunikasi yang terjadi adalah untuk mencapai persetujuan pihak lain terkait cara-cara suatu kelompok dalam mengekspresikan dirinya, sehingga mendapatkan legitimasi. Proses komunikasi konvergen ini berjalan baik karena dimediasi oleh adanya 
keberlanjutan keberadaan komunitas tagar sehingga komunitas tagar menjadi identitas suatu kelompok sebagai wadah dalam menyampaikan ide, informasi, pendapat, dukungan dan penolakan terhadap suatu informasi atau isu. Proses komunikasi juga dimediasi oleh kemunculan momenmomen nasional seperti hari kemerdekaan, hari raya Idul Fitri atau Natal, di mana momen-mamen ini memberi energi rasa nasionalisme yang muncul menjadi lebih kuat serta membuat hati dan pikiran lebih terbuka pada ide-ide yang mempersatukan dari pada ide yang berpotensi memecah belah. Komunikasi antar kelompok tagar juga dapat mencapai konvergensi karena peristiwaperistiwa seperti bencana alam, musibah, baik yang disebabkan oleh manusia maupun karena unsur lainnya.

Selain diskusi tentang cara-cara berekspresi untuk mendapatkan persetujuan publik, terdapat pula diskusi yang membahas pembuktian-pembuktian baik berupa argumen, data data, terutama data terbaru, dan dampak komunitas tagar di dalam kehidupan sosial kemasyarakatan. Temuan ini sesuai dengan temuan penelitian Pamungkas \& Octaviani, (2017). Dalam penelitian ini yang masuk dalam kategori tersebut adalah tagar makar, tagar NKRI harga mati, dan tagar Indonesia damai. Masuknya komunitas tagar yang terpolarisasi kedalam tagar bersama yaitu tagar makar, NKRI harga mati dan Indonesia damai membuka ruang diskusi antartagar terkait ekspresi yang tepat terkait makna makar, NKRI harga mati dan Indonesia damai dengan saling mengkomunikasikan bukti-bukti baik berupa argumen yang disetujui, data yang divalidasi dan bukan hoaks serta dampaknya bagi kehidupan bersama. Tagar-tagar ini terutama dimediasi oleh keberadaan komunitas tagar yang terus berlanjut yang menjadi wadah dalam menyampaikan pendapat. Tagar tagar ini juga dimediasi oleh informasi baru, penemuan data baru, dan informasi atau kejadian konflik baru. Pada komunitas tagar makar, NKRI harga mati dan Indonesia damai, konvergensi komunikasi bersifat temporal. Ketika suatu akun membagikan data baru atas suatu isu misalnya berupa foto atau yang lainnya, maka diskusi akan terjadi terkait keaslian data tersebut hingga mencapai kesepakatan atas keaslian atau kepalsuan data tersebut. Karena membahas hal-hal baru, baik data, kejadian konflik baru ataupun dampak-dampak yang dinamis di tengah-tengah masyarakat, maka diskusi dalam tagar-tagar inipun bersifat dinamis dan berkelanjutan, terkadang terjadi kesepahaman, di saat yang lain tidak terjadi kesepahaman.

Keberlanjutan Perdebatan dan dinamisasi kesepakatan banyak terjadi pada tagar makar, tagar NKRI harga mati, dan tagar Indonesia damai. Dalam proses komunikasi yang terjadi terlihat bahawa ketiga tagar ini memperdebatkan komitmen masing-masing kelompok terhadap kesatuan Indonesia, menjaga kedamaian dan menjauhkan aksi kelompoknya dari terindikasi makar. Diskusi yang dinamis menyebabkan partisipan terus bertambah, bukan saja dari kelompok-kelompok yang tadinya terpolarisasi, namun juga partisipan yang tidak berafiliasi dengan dua kelompok besar yang terpolarisasi. Hal ini berdampak pada semakin beragamanya ide yang muncul karena tidak selalu dikaitkan pada isu besar yang terpolarisasi. Percakapan yang lebih ramah dan tidak melibatkan emosi yang berlebihan dalam membela isu kelompok ini berhasil memunculkan keinginan mencapai tujuan bersama yaitu kebaikan kehidupan sosial bersama sebagai warga negara Indonesia. Pola ini menunjukkan tagar sebagai pusat struktur yang membangun pola komunikasi di media sosial Twitter dapat mewadahi keragaman komunitas yang muncul. (Gambar 4) 


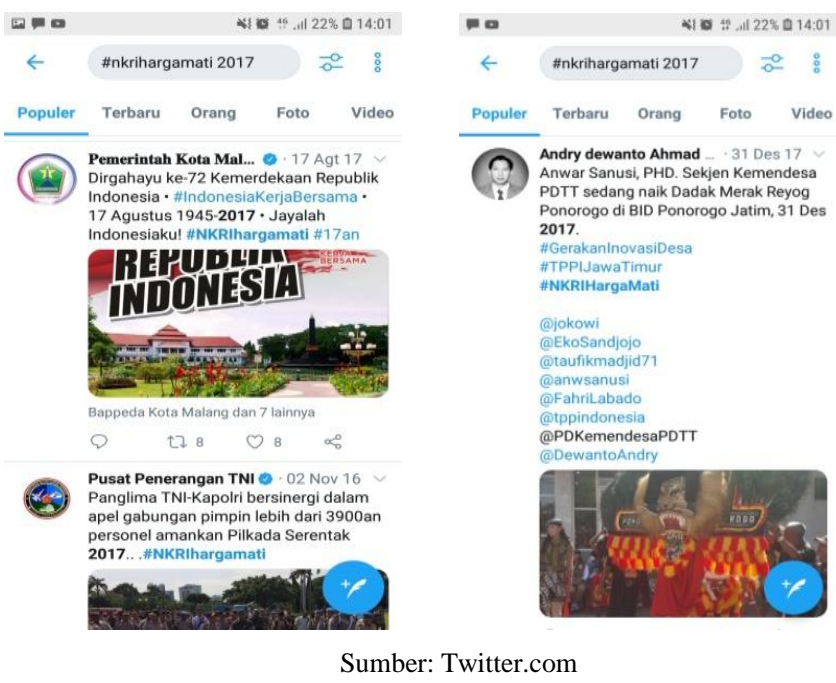

Gambar 4. Keragaman Kelompok, Ide dan Argumentasi di Ruang Publik Virtual Menjadikan Komunikasi Bersifat Dialogis dan Konvergen.

\subsection{Fungsi Tagar dalam Pergaulan Komunitas Virtual Twitter}

Keseluruhan proses kemunculan kelompok-kelompok yang merespon isu penegakan hukum atas penistaan agama dimediasi oleh tagar atau tanda pagar yang merupakan simbol dari pergaulan yang muncul di internet dalam hal ini Twitter. Tanda pagar atau tagar digunakan oleh masyarakat Twitter sebagai simbol pergaulan yang berfungsi antara lain sebagai cara untuk menunjukkan identitas diri (Alrasheed, 2017). Dalam penelitian ini, tagar aksi bela Islam berfungsi untuk menunjukkan identitas diri dalam menyikapi isu penegakan hukum atas penistaan agama. Dengan menyertakan tagar aksi bela Islam atau tagar bubarkan ormas radikal FPI pada awal atau akhir suatu percakapan menunjukkan pandangan pemilik akun terkait penegakan hukum atas penistaan agama. Pada fenomena penegakan hukum atas penistaan agama, akun-akun yang menggunakan tagar baik aksi bela Islam maupun bubarkan ormas Islam radikal FPI banyak yang menyertakan lebih dari satu tagar. Akun yang mengidentifikasi diri sebagai kelompok aksi bela Islam misalnya, juga menyertakan tagar tangkap Ahok, NKRI bersyariah, nasionalis, makar dan Indonesia damai. Hal ini menunjukkan bahwa selain digunakan untuk menunjukkan identitas pemilik akun, tagar juga digunakan sebagai cara menyampaikan rangkaian ide atas suatu isu. Pemilik akun ingin menyampaikan bahwa selain sebagai kelompok tagar aksi bela Islam, dirinya juga adalah kelompok yang lainnya sebagaimana tagar-tagar yang disertakan. Artinya dalam menyikapi isu penegakan hukum atas penistaan agama pemilik akun ingin menyampaikan bahwa aksi bela Islam juga bagian dari tagar nasionalis, NKRI harga mati dan Indonesia damai, dan bahwa pemilik akun juga adalah bagian dari komunitas NKRI bersyariah sebagai bentuk pemikirannya menyikapi penistaan agama. Menjadi bagian dari kelompok eksklusif dan kelompok inklusif sekaligus menunjukkan bahwa tagar juga digunakan sebagai simbol melakukan negosiasi di antara berbagai komunitas yang berinteraksi yaitu dengan cara menyertakan banyak tagar pada suatu tweet atau percakapan.

Dari terjadinya negosiasi di antara kelompok kelompok yang berinteraksi ini menunjukkan bahwa tagar dijadikan simbol dalam menawarkan solusi-solusi terkait isu penegakan hukum atas penistaan agama. Tingginya interaksi pada tagar NKRI harga mati, makar dan Indonesia damai, menunjukkan bahwa dari kedua belah pihak yang terpolarisasi sama-sama mencoba menawarkan solusi tentang makna makar dan bukan makar, makna NKRI harga mati dan makna Indonesia damai. Pada tagar inklusif, selain dibagikan bersamaan dengan tagar aksi bela Islam, tagar bubarkan ormas Islam radikal FPI, juga dibagikan oleh akun yang tidak menyertakan tagar yang 
terpolarisasi. Hal ini menunjukkan semakin beragamnya komunitas yang masuk dalam interaksi tersebut sehingga polarisasi menjadi tidak lagi keras dan percakapan pun bersifat lebih cair, terbuka dan beretika.

Interaksi yang lebih terbuka akibat munculnya tagar dengan narasi yang sama meskipun pemaknaannya beragam, disertai masuknya komunitas-komunitas baru yang tidak terpolarisasi, menunjukkan bahwa tagar juga digunakan sebagai proses perkembangan pemikiran dalam menyikapi isu penegakkan hukum atas penistaan agama. Pada tagar aksi bela Islam perkembangan dalam menyikapi isu terlihat pada upaya-upaya menghindari sikap ataupun perkataan yang akan mengakibatkan pemaknaan makar atas aksi bela Islam, mengupayakan tertib dalam demo, dan menunjukkan sikap sebagai warga Negara Indonesia yang baik. Pada tagar bubarkan ormas Islam radikal FPI perkembangan dalam menyikapi isu penegakan hukum atas penistaan agama terlihat dari ditujukannya kritik terhadap aksi aksi yang dipandang radikal bukan saja pada aksi bela Islam, serta menyikapi demo aksi bela Islam sebagai bagian dari hak menyatakan pendapat yang sah secara konstitusional selama menjaga kemanan, ketertiban dan kedamaian komunitas lainnya yang tidak ikut berdemo. Pada tagar-tagar inklusif, perkembangan isu terlihat dari terus berkembangnya narasi-narasi yang lebih dapat diterima publik seperti diskusi-diskusi seputar pembuktian tidak makar dengan menjaga Indonesia agar tetap damai, NKRI harga mati dan sebagainya. Dari palapola inilah dapat diketahui bahwa simbol tagar digunakan sebagai upaya mengembangkan pandangan dalam menyikapi isu dalam hal ini penegakan hukum atas penistaan agama. Sebagaimana gambar berikut: (Gambar 5).

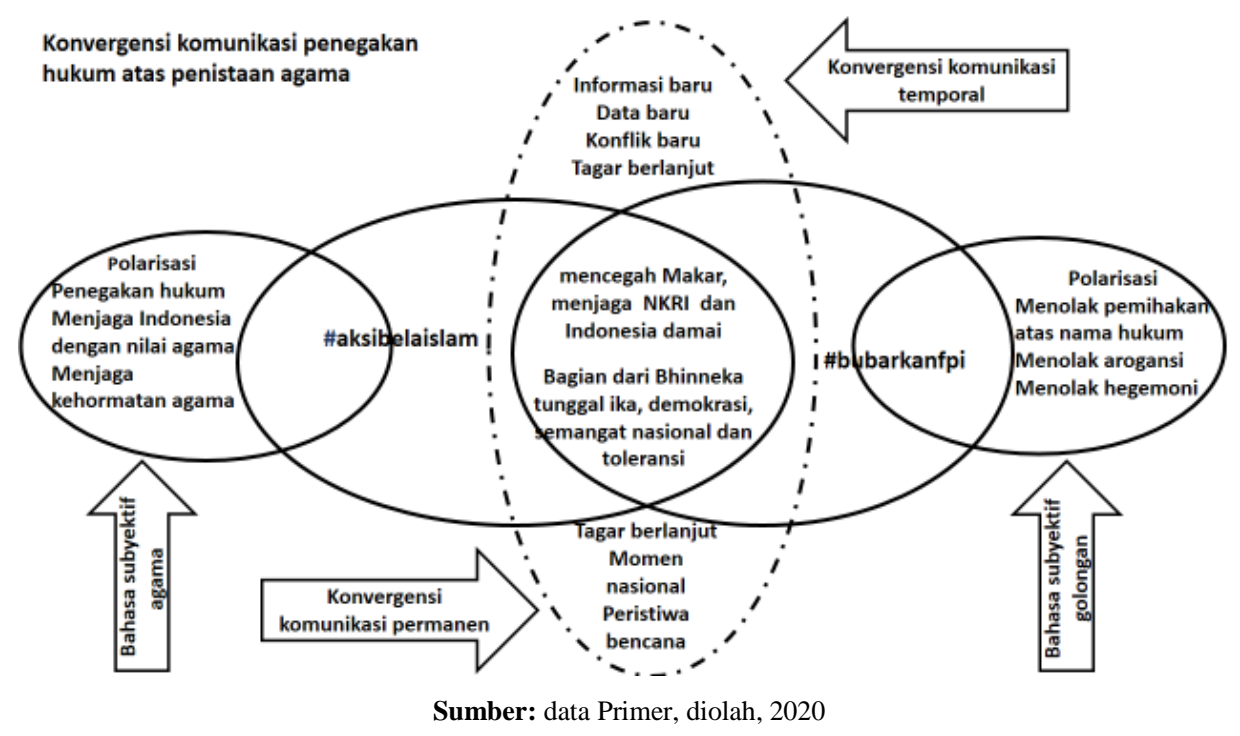

Gambar 5. Makna Jaringan Komunikasi Warganet Twitter

\section{PENUTUP}

Media sosial Twitter memberi ruang terbuka bagi warganet untuk mengekspresikan kebebasan menyatakan pendapat dan kebebasan berserikat. Disisi lain kebutuhan pada tercapainya kehidupan sosial yang harmonis membuat masyarakat membangun komunikasi yang bersifat menyebar, terbuka, dialogis dan konvergen di ruang publik virtual dan menghasilkan solusi-solusi dalam mengelola konflik. Kedua kondisi ini menunjukkan adanya kemampuan berpartisipasi secara politis di tingkat akar rumput. Namun masih terdapat hambatan yang dapat mencederai partisipasi dan komunikasi politik yang sehat berupa nilai-nilai eksklusif kelompok yang dibawa ke ruang publik dengan tujuan melakukan hegemoni ruang publik, dan cara pemerintah dalam menangani konflik 
yang justru menguatkan polarisasi. Keseluruhan kondisi yang tercipta di ruang publik virtual ini pada fenomena aksi bela Islam mengakibatkan terjadinya tarik menarik antara eksklusivitas kelompok dengan inklusivitas tujuan bersama sebagai warga Negara Indonesia. Keberlanjutan momen aksi bela Islam menjadikan kondisi tarik menarik ini juga menjadi berkelanjutan yang membuat kesepakatan-kesepakatan yang dicapai bersifat tidak permanen. Artinya di saat tertentu warganet berhasil mencapai kesepakatan perihal makna aksi bela Islam dan meredakan konflik, di saat yang lain kesepakatan tidak tercapai dan mengakibatkan konflik yang berkelanjutan.

Kondisi ini dapat ditangani dengan cara menyeimbangkan antara keragaman partisipasi politik warga dengan kemampuan pemerintah dalam memediasi keragaman yang ada di ruang publik virtual untuk melakukan negosiasi dengan lebih baik, yaitu tidak hanya terjadi di ruang publik virtual namun juga mencoba melakukan negosiasi secara nyata berdasarkan kebutuhan harmonisasi kehidupan sosial bersama. Untuk mencapai hal tersebut pemerintah perlu mengembangkan pemahaman pada fenomena partisipasi akar rumput beserta tujuan-tujuannya, serta menjaga jarak dari keberpihakan pada kelompok tertentu dan membuat kelompok lain seolah-olah menjadi penentang pemerintah, di mana hal tersebut justru mempertajam konflik di tingkat akar rumput.

\section{Ucapan Terima Kasih}

Karya tulis ilmiah ini dapat selesai dengan baik berkat bantuan banyak pihak. Karena itu, saya ingin menyampaikan terima kasih kepada pembimbing Disertasi saya Prof. Dr. Sumardjo, M.S beserta tim, serta semua pihak yang sudah membantu baik dalam proses pengumpulan data maupun pada saat diskusi-diskusi yang hangat. Terima kasih juga untuk Kementerian Kominfo yang telah berkenan menerbitkan tulisan ini.

\section{DAFTAR PUSTAKA}

Abdullah, A. (2017). Membaca Komunikasi Politik Gerakan Aksi Bela Islam 212: Antara Politik Identitas Dan Ijtihad Politik Alternatif [Reading the Political Communication of the Islamic Defense Action Movement 212: Between Identity Politics and A. An-Nida: Jurnal Pemikiran Islam, 41(2), 202-212.

Ahmadian, S., Azarshahi, S., \& Paulhus, D. L. (2017). Explaining Donald Trump via communication style: Grandiosity, informality, and dynamism. Personality and Individual Differences, 107, 49-53. https://doi.org/10.1016/j.paid.2016.11.018

Alrasheed, G. (2017). Tweeting Towards Utopia: Technological Utopianism and Bloc juga dah ada, abdullah itu saya kirim jurnalnya, eriyanto itu buku.. gmn ya.. 口Academic Discourse on Political Movements in the Middle East and North Africa [Carleton University]. https://doi.org/10.22215/etd/2017-12006

Anderson, B. (2017). Tweeter-in-Chief : A Content Analysis of President Trump's Tweeting Habits. Elon Journal of Undergraduate Research in Communications, 8(2), 36-47.

Ausserhofer, J., \& Maireder, A. (2013). National Politics On Twitter, Information, Communication \& Society. Information, Communication \& Society, 16(3), 291-314. https://doi.org/10.1080/1369118X.2012.756050

Block, E., \& Negrine, R. (2017). The Populist Communication Style: Toward a Critical Framework. International Journal of Communication, 11, 178-197.

Bos, L., \& Brants, K. (2014). Populist rhetoric in politics and media: A longitudinal study of the Netherlands. European Journal of Communication, 29(6), 703-719. https://doi.org/10.1177/0267323114545709

CNN Indonesia. (2019). Bubarkan FPI Jadi 'Trending', Status WNI Rizieq Dipersoalkan. https://www.cnnindonesia.com/nasional/20190610104045-20-402018/bubarkan-fpi-jadi-trendingstatus-wni-rizieq-dipersoalkan

Fadhil, H. (2016). Tertibnya Massa Aksi 2 Desember: Duduk Khusyuk, Tak Duduk di Rumput. https://news.detik.com/berita/d-3360622/tertibnya-massa-aksi-2-desember-duduk-khusyuk-tak-duduk- 
di-rumput

Hamudy, N. A. (2019). Jurnal bina praja. Jurnal Bina Praja, 11(2), 197-207. https://doi.org/10.21787/jbp.11.2019.197-207

Hapsari, D. R., Sarwono, B. K., \& Eriyanto, E. (2017). Jaringan Komunikasi Dalam Partisipasi Gerakan Sosial Lingkungan: Studi Pengaruh Sentralitas Jaringan terhadap Partisipasi Gerakan Sosial Tolak Pabrik Semen Pada Komunitas Adat Samin di Pati Jawa Tengah. Jurnal Komunikasi Indonesia, 6(2), 120-128. https://doi.org/10.7454/jki.v6i2.8712

Jr, G. M. B. (2010). Netnography: A Method Specifically Designed to Study Cultures and Communities Online Netnography: A Method Specifically Designed to Study Cultures and Communities Online.

Juditha, C. (2015). Phenomenon On Twitter: Discourse Analysis Of Tweet \# Savehajilulung. Jurnal Penelitian Komunikasi Dan Pembangunan, 16(2), 138-154.

Juditha, C. (2017). Hatespeech Di Media Online: Kasus Pilkada Dki Jakarta 2017. Jurnal Ilmu Komunikasi, $137-150$.

Juditha, C. (2019). Dukungan Sosial Warganet Di Twitter Terhadap Gaya Komunikasi Pasangan Calon Presiden Pada Debat Pemilu 2019 [Social Support of Warganet on Twitter for the Communication Style of Presidential Candidates in the 2019 Election Debate]. Jurnal Studi Komunikasi Dan Media, $87-100$.

Khamdan, M., \& Wiharyani, W. (2018). Mobilisasi Politik Identitas dan Kontestasi Gerakan Fundamentalisme [Mobilization of Identity Politics and the Contestation of Fundamentalism Movements]. Al-Tahrir: Jurnal Pemikiran Islam, 18(1), 193. https://doi.org/10.21154/altahrir.v18i1.1198

Kozinets, C., Robert, V., Dolbec, P., \& Earley, A. (2015). Netnographic Analysis : Understanding Culture through Social Media Data. In Uwe Flick, ed. Sage Handbook of Qualitative Data Analysis (pp. 262 275).

Lim, M. (2017). Freedom to hate: social media, algorithmic enclaves, and the rise of tribal nationalism in Indonesia. Critical Asian Studies, 49(3), 411-427. https://doi.org/10.1080/14672715.2017.1341188

Nasrullah, N. (2017). GNPF-MUI: Tuntutan Aksi Bela Islam Hanya Tegakkan Hukum untuk Ahok. https://www.republika.co.id/berita/nasional/hukum/17/01/02/oj4rb9320-gnpfmui-tuntutan-aksi-belaislam-hanya-tegakkan-hukum-untuk-ahok

Negara, S. B. (2020). Dinamika Relasi dan Kuasa Negara dalam Produksi Konten di Media Siber Pemerintah Menjelang Pemilihan Umum Presiden 2019. Jurnal Studi Komunikasi Dan Media, 24(1), 57. https://doi.org/10.31445/jskm.2020.2425

Pamungkas, A. S., \& Octaviani, G. (2017). Aksi Bela Islam dan Ruang Publik Muslim: Dari Representasi Daring ke Komunitas Luring [Action to Defend Islam and Muslim Public Spheres: From Online Representation to Offline Communities]. Jurnal Pemikiran Sosiologi, 4(2).

Ridhoi, M. A. (2018). Merayu Pendukung Ahok Agar Tak Golput, Kunci Kemenangan Jokowi. https://tirto.id/merayu-pendukung-ahok-agar-tak-golput-kunci-kemenangan-jokowi-cRRG

Rofi'ah. (2013). Efektifitas Komunikasi Antar Budaya (Kasus Manajemen Konflik Suku Sunda dan Suku Madura di Kelurahan Kebon Kelapa Bogor).

Sumardjo. (2008). Penyuluhan Pembangunan: Pilar Pendukung Kemajuan dan Kemandirian Masyarakat." Dalam Pemberdayaan Manusia Pembangunan yang Bermartabat (A. Sudrajat \& I. Yustina (eds.)). Sydex Plus.

Sumardjo. (2010). Penyuluhan Menuju Pengembangan Kapital Manusia, dan Kapital Sosial Mewujudkan dalam Mewujudkan Kesejahteraan Rakyat. In Orasi Ilmiah Guru Besar Tetap Fakultas Ekologi Manusia.

Sumardjo. (2015). Model Pemberdayaan Masyarakat Dan Pengelolaan Konflik Sosial Pada Perkebunan Kelapa Sawit Di Propinsi Riau (Issue 11).

Susilowati, I., Yunus, N. R., \& Sholeh, M. (2019). Politics Of Identity On Great 212 ' S Reunion. Dauliyah, $4(1), 59-79$.

Syahputra, I. (2017). Demokrasi Virtual Dan Perang Siber Di Media Sosial: Perspektif Netizen Indonesia [Virtual Democracy and Cyber War on Social Media: The Perspective of Indonesian Netizens]. Jurnal 
ASPIKOM, 3(3), 457. https://doi.org/10.24329/aspikom.v3i3.141

Wardani, A. S. (2017). Sidang Vonis, Cuitan Soal Ahok Paling Ramai di Linimasa Twitter. https://m.liputan6.com/tekno/read/2945613/sidang-vonis-cuitan-soal-ahok-paling-ramai-di-linimasatwitter

Wijayanto, T. D., \& Purworini, D. (2018). Respon Pemerintah Pada Aksi Damai 411 Dan 212 : Analisis Isi Harian Kompas Edisi November 2016 - Desember 2016. Komuniti, 10(1), 11-25. 